\title{
Recenzja książi Andrzeja Nowaka, Pierwsza zdrada zachodu. 1920 - zapomniany appeasement, Kraków 2015, 603 s.
}

\begin{abstract}
Review: Andrzej Nowak, The First Betrayal of the West. 1920 - Forgotten Appeasement, Kraków 2015, 603 p.

What is innovative in this study of the West's attitude towards the Polish army struggling alone against Bolshevik Russia is the presentation of the discussed issue based on the rich archives of Great Britain, the USA, Russia, Switzerland, and Poland. The extensive basis is the collection of documents and printed sources as well as press articles and studies. The monograph is a very valuable item due to the quotation of many unknown or little-known archival sources, which brings readers closer to the "Polish cause" of the politicians of the great powers, deciding then on the fate of the European continent. The most interesting part of the monograph is the third part, in which the author attempted to reach, based on unused documents, the reasons for the attitude of appeasement, i.e. the attempt by the Entente states to calm down Bolshevik Russia, at the expense of the smaller states of the central-eastern part of the European continent. It is a rich psychological analysis of the motives of attitudes of the most influential politicians of that era, towards a settlement with the new rulers of Moscow. The publication is an exceptional and very carefully published work, which also contains little-known photographs from the era when the fate of the Polish Republic was weighing in the balance. In the event of a defeat in the war with Bolshevik Russia, Poland would have been thrown into the abyss of communist hell, in the cruel Russian variety met by other nations, and would have lost its independence in 1920. It most probably would not have regained it in 1945, even in the much truncated form of the eventual reality of the Polish People's Republic. Particularly noteworthy is the captivating style of the narrative and, most importantly, the firm assumption of theses, based mostly on quotes from sources, which, naturally, is extremely convincing for the reader. All this makes this academically valuable monograph worth recommending to a wide range of readers.
\end{abstract}

Keywords: attitude of Western states towards Poland, yielding to Russia, valuable source basis of the monograph

Słowa kluczowe: postawa państw zachodnich wobec Polski, ustępliwość wobec Rosji, wartościowa podstawa źródłowa monografii 
Wojnę z bolszewicką Rosją w 1920 roku opisują już liczne publikacje. Nieznane szerzej są natomiast aspekty międzynarodowe tego militarnego konfliktu, a szczególnie stosunek zwycięskich mocarstw zachodnich (w I wojnie światowej) i rządów krajów sąsiednich do Rzeczypospolitej walczącej z nacierającą Armią Czerwoną, prącą bezwzględnie do podboju Polski i Europy.

Kolejna monografia autorstwa znanego historyka Andrzeja Nowaka o postawie Zachodu wobec samotnie walczącej armii polskiej jest znaczącym uzupełnieniem tej problematyki.

Nowatorstwem tego obszernego opracowania jest ukazanie omawianej problematyki na podstawie bogatych archiwaliów Wielkiej Brytanii (Londyn, Edynburg, Cambridge, Oxford), Stanów Zjednoczonych Ameryki (Nowy Jork i Waszyngton), Rosji (Moskwa), Szwajcarii (Raperswil) i Polski (Zakład Narodowy im. Ossolińskich we Wrocławiu). Poza tym obszerną podstawę stanowią publikowane zbiory dokumentów i źródła drukowane, a także artykuły prasowe oraz opracowania.

Autor zastosował podział całości na cztery części, z których każda dzieli się na mniejsze podrozdziały. Monografia zawiera także wykaz archiwaliów, bibliografię, źródła ikonografii oraz indeks nazwisk.

Część pierwsza zawiera opis planów ukształtowania powojennej Europy przez zwycięskie mocarstwa zachodnie, szczególnie regionu środkowoeuropejskiego, po rozpadzie Austro-Węgier. Najbardziej cenna w tej części monografii jest analiza postaw najważniejszych polityków zachodnich wobec hipotetycznej „białej” Rosji (jakby to miało być pewne, że kiedykolwiek powróci), aby tylko nie została zbytnio pomniejszona na rzecz mniejszych narodów. Po prostu władzę bolszewicką traktowano jako system zupełnie przejściowy, który rychło się zawali i nadal na wschodzie Europy to Rosja będzie przeciwwagą dla zagrożenia agresją ze strony Niemiec. Niestety taka postawa cechowała zwłaszcza prezydenta USA Thomasa Woodrowa Wilsona, który traktował Rosję jak wielkiego sojusznika z czasów I wojny światowej, teraz wymagającego pomocy. Postrzegał ją również jako wielkiego producenta żywności, co miało mieć wprost kluczowe znaczenie dla gospodarki świata, oraz jako gigantyczny rynek zbytu dla amerykańskich towarów, szczególnie po zniszczeniach wojennych we wschodniej Europie.

Wyjątkowo celnie autor stwierdził, iż „Wilson był przekonany, że bolszewizm pokona się nie siłą militarną, ale poprzez odbudowę ekonomiczną i moralną, której beneficjentem powinien być «lud rosyjski», jedyny uprawniony gospodarz (wielkiej) Rosji. $Z$ góry należy więc uznać - według Wilsona - każdą interwencję zewnętrzną za skazaną na fiasko. Tylko sami Rosjanie mogą odrzucić bolszewizm. Należy dać im szanse - zdaniem prezydenta USA - na uspokojenie, na odnowę gospodarczą, na wymianę - a nie walkę - ze światem zewnętrznym. Wtedy bolszewicy stracą poparcie. Wzrośnie ono natomiast, kiedy będą mogli występować jako obrońcy całości terytorium dawnego imperium przed roszczeniami" małych narodów pragnących oderwać się od Rosji1.

Naiwność takiego rozumowania przywódcy USA można wytłumaczyć dwojako; po pierwsze dla polityków amerykańskich w polityce zawsze pierwszoplanową rolę grał

1 A. Nowak, Pierwsza zdrada zachodu. 1920 - zapomniany appeasement, Kraków 2015, s. 97, 98. 
pieniądz, a po drugie - był to zupełny brak rozeznania o stopniu koszmaru życia w bolszewickiej Rosji².

Z początkiem 1920 roku Stany Zjednoczone zaczynały już odsuwać się od spraw europejskich; 19 marca Senat USA odmówił ratyfikowania traktatu wersalskiego, a wśród polityków amerykańskich zaczął przeważać pogląd, że każda samodzielna akcja wojskowa Polaków przyniesie tylko kłopoty. Jednak latem 1920 roku, kiedy to Armia Czerwona rozpoczęła inwazję na Polskę, to poseł amerykański w Warszawie apelował do władz brytyjskich o pomoc dla samotnie walczącej Rzeczypospolitej, za to jego odpowiednik w Londynie odpowiadał usilną prośbą, aby przekonywał prezydenta USA o wyrażenie zgody na rozpoczęcie negocjacji z bolszewicką delegacją na planowanej przez brytyjskiego premiera wielkiej konferencji międzynarodowej, na której miano skorygować postanowienia zawarte $\mathrm{w}$ traktacie wersalskim. Tym bardziej że od 4 sierpnia 1920 roku w Londynie przebywała już rosyjska delegacja z Lwem Kamieniewem (jednym z najwyższych dygnitarzy Rosji; właśc. nazwisko: Rozenfeld) i Leonidem Krasinem³ Premier brytyjskiego rządu Dawid Lloyd George usiłował przekonać prezydenta USA do swojej prorosyjskiej postawy, i jednocześnie wyraźnie antypolskiej, pisząc (w liście z 5 sierpnia), że „Polacy są wcieleniem perwersyjnej nieudolności. To jakby próbować ratować tonącego człowieka, który robi wszystkie głupie rzeczy, których nie powinien, i nie robi nic z tego, o co się go błaga"4, a to „błaganie” wyglądało tak, że 10 sierpnia premier Wielkiej Brytanii w angielskim parlamencie, w obecności Kamieniewa (w Galerii Znakomitych Gości) zaakceptował wszystkie warunki, jakie rząd Lenina przedstawił w swoim brutalnym dyktacie, którego przyjęcie przez władze polskie równałoby się zupełnemu skomunizowaniu Rzeczypospolitej, a zapewne w dalszej perspektywie - włączeniu do bolszewickiej Rosji. Stosunek władz USA do rozstrzygnięć zawartych w traktacie wersalskim oddaje między innymi brak uznania niepodległości państw bałtyckich.

Należy przyznać, że kiedy Armia Czerwona zaciekle atakowała przedpola Warszawy, a niemieccy dokerzy odmówili rozładunku dostaw wojennych w porcie gdańskim, to jednak rządy Francji i Anglii usiłowały odblokować port, zwracając się również o pomoc do prezydenta USA, który ,z furią” odmówił wysłania nawet jednego okrętu do Gdańska. Stosunek przywódcy Wilsona do komunistycznych władców Kremla najlepiej oddaje list wysłany do brytyjskiego premiera (już po zakończeniu działań wojennych polsko-rosyjskich, jesienią 1920 roku), w którym wyraźnie uzasadniał swoją bierną po-

2 Jednym z nielicznych polityków zachodnich, który zrozumiał, co rosyjski bolszewizm może przynieść całemu światu, był brytyjski minister wojny Winston Churchill, który dostrzegł, ze w Rosji doszło do straszliwego kataklizmu, a potworność bolszewickiej dyktatury unaoczniło wymordowanie bez wyroku sadowego carskiej rodziny - na rozkaz Włodzimierza Lenina (właśc. nazwisko - Ulianow). Późniejszy premier (w okresie II wojny światowej) zrozumiał również, ze świat ma przed sobą nowy, nieznany dotychczas, stopień barbarzynstwa, całkowicie obojętny na - od wieków powszechnie przyjęte - normy współżycia ludzkości. W 1919 r. wyjątkowo trafnie podsumował: „Ze wszystkich tyranii w historii bolszewicka jest najgorsza, najbardziej niszczycielska, najbardziej poniżająca, a okrucieństwa Lenina są bez porównania wstrętniejsze, bijące skalą i liczba ofiar, wszystko to, za co odpowiedzialność ponosi niemiecki cesarz", cyt. za: P. Johnson, Historia świata (od 1917 r.), Londyn 1989, s. 82.

3 Warto dodać, że po bolszewickich reprezentantów władz rosyjskich przypłynął brytyjski niszczyciel do estońskiego portu w Rewlu (dzisiaj Tallin), do tego stopnia Anglikom zależało na dojściu do porozumienia z bolszewicką Rosją, A. Nowak, Pierwsza zdrada..., s. 178.

4 Cyt. za: A. Nowak, Pierwsza zdrada zachodu..., s. 102. 
stawę wobec rosyjskiego bolszewizmu, pisząc: „Co do Rosji, to nie mogę oprzeć się wrażeniu, że bolszewizm sam by się wypalił, gdyby go tylko zostawić w spokoju..."

Do jakiego stopnia trzeba było nie mieć nawet elementarnego rozeznania na temat tego, co działo się w tym czasie w wielonarodowościowej Rosji ogarniętej szałem bolszewickiego, „czerwonego terroru” (gdzie mordowano całe kręgi zawodowe i społeczne oraz grupy etniczne), aby nie rozumieć, że komunizm to po prostu zło absolutne!

W części drugiej ukazano postawę premiera Wielkiej Brytanii wobec bolszewickiej Rosji i Rzeczypospolitej w czasie walk z Armią Czerwoną do połowy sierpnia 1920 roku. Był to czas, jak to Autor celnie ujął, starań o zawarcie z Rosją ,pokoju przez handel" i rozpoczęcia negocjacji z przedstawicielami władz rosyjskich w Londynie, co jednak zburzył ,pochód na Kijów” polskiej armii w celu oderwania Ukrainy od Rosji.

Brytyjski premier posunął się - jak podaje autor - nawet do tego, że pomimo absurdalnych żąań kapitulacji wobec polskich władz rosyjskiego szefa MSZ, próbował przekonać własnych ministrów, iż „alternatywą dla kontynuowania rozmów z Moskwą jest wchłonięcie Polski przez Rosję sowiecką..."'. Niestety dla brytyjskiego premiera „Polska mogła nawet zniknąć” - jak słusznie podsumował postawę angielskiego polityka autor - ,a Londyn by to przełknął, byle tylko Rosja sowiecka ograniczyła do kraju nadwiślańskiego swe apetyty rewizji geopolitycznej sytuacji w Europie" brytyjskich polityków los Rzeczypospolitej był już przesądzony.

Winston Churchill w artykule „Niebezpieczeństwo zatrucia ze wschodu” (na łamach „Evening News”) uznał, że Polska była „zwornikiem systemu wersalskiego” i jeśli zostanie wchłonięta przez bolszewicką Rosję, to runie cały system europejski ukształtowany w Wersalu. Nie tylko jednak nie wierzył, że Polacy sami mogą uratować swój kraj, ale nawet, że po tak krwawej wojnie światowej mogłyby tego dokonać wojska mocarstw zachodnich. Ratunek dla konającej Polski widział tylko w armii... niemieckiej. Nie zdawał sobie po prostu sprawy, że rząd niemiecki skrycie wspomagał już Armię Czerwoną̧, sądząc, że rząd Lenina nasyci się terenami należącymi do carskiej Rosji przed 1914 rokiem (tzw. Kongresówką), a Niemcy odzyskają Wielkopolskę i Pomorze Gdańskie.

Ibidem, s. 111.

6 Ibidem, s. 175.

Ibidem, s. 176.

8 Należy przypomnieć, że w czasie wojny z bolszewicką Rosją pozostawiona w osamotnieniu na północnym Mazowszu IV Armia Rosyjska została wprawdzie rozbita, lecz część żołnierzy wraz z III Korpusem Konnym Gaj-chana, w celu uniknięcia polskiej niewoli, przekroczyła granicę polsko-niemiecką w Prusach Wschodnich, gdzie „krasnoarmiejcy” powinni byli zostać rozbrojeni i internowani do czasu zakończenia działań wojennych, zgodnie z przyjętymi normami międzynarodowymi. Obowiązuje to każde państwo neutralne. Rząd niemiecki, pomimo oficjalnego ogłoszenia neutralności (20 lipca 1920 roku), pozwolił jednak rosyjskim żołnierzom przejść przez swoje terytorium i rzekę Niemen (około 30 tysiącom) i dołączyć do bolszewickich dywizji rezerwowych. Od razu stanęli oni ponownie do wojny z Polską, P. Madajczyk, Niemcy wobec wojny polsko-radzieckiej $1920 \mathrm{r}$. [w:] Wojna polsko-radziecka 1920 roku, red. A. Koryn, Warszawa 1991; B. Piotrowski, Groźba rozbioru Polski w 1920 r. Niemcy a wojna polsko-bolszewicka, „Życie i Myśl”" 1990, nr 7-8; W. Petter, Niemcy i Reichswehra w wojnie polsko-sowieckiej (1919-1920) [w:] Rok 1920. Z perspektywy osiemdziesięciolecia, red. A. Ajnenkiel, Warszawa 2001, s. 255; K. Jońca, Internowanie polskich i radzieckich żotnierzy w Prusach Wschodnich podczas wojny w 1920 roku, Wrocław 1996; G. Łukomski, Współdziatanie niemiecko-bolszewickie przeciw Polsce w latach 1918-1920, „Mars” 1993, t. 1, s. 35-46; M. Pirko, Z dziejów wspótpracy Armii Czerwonej z Reichswehrą w latach 1920-1933, „Wojskowy Przegląd Historyczny" 1992, nr 2, s. 41-61. 
W Berlinie nie rozumiano, że rosyjskie dywizje parły już bezwzględnie nie tylko do podboju samotnie walczącej Polski, ale również do podboju europejskiego kontynentu9 .

Monografia jest bardzo wartościową pozycją ze względu na cytowanie wielu nieznanych lub mało znanych źródeł archiwalnych, co bardzo przybliża czytelnikom stosunek do „sprawy polskiej” polityków wielkich mocarstw, decydujących wówczas o losach europejskiego kontynentu. Jaskrawym przykładem może być fragment korespondencji szefa misji angielskiej w Polsce w 1920 roku, lorda Edgara d'Abernona, który w książce pt. Osiemnasta decydująca bitwa $w$ dziejach świata uznał zwycięstwo w wojnie z bolszewicką Rosją za jedno z najważniejszych w dziejach, ale latem 1920 roku (dokładnie 9 sierpnia tegoż roku) w raporcie i korespondencji do Londynu twierdził, że jeśli nad Polakami nie umieści się „europejskich” nadzorców we wszystkich działach administracji, to nigdy nie zbudują normalnie funkcjonującego kraju, ponieważ „muszą pożyczyć rozum i stateczność"10.

Innym politykiem, którego cytuje autor, był lord George Curzon, który z całą beztroską twierdził, że „Polska jest oczywiście idealnym krajem do toczenia w nim wojen. [...] O ile Liga Narodów nie sprawdzi się całkowicie w swoim obecnym kształcie, to można by, poprzez niewielką zmianę jej obecnego statutu, ustanowić Polskę areną do rozstrzygania konfliktów przez toczenie «na jej terenie» zastępczych walk przez wybrane oddziały ze skonfliktowanych krajów" "11. Miał to być zatem kraj-poligon, na którego terenie miały odbywać się swoiste europejskie „wojny-turnieje” (jak to trafnie określił autor).

W rozmowach z francuskim prezydentem Aleksandrem Millerandem, latem 1920 roku brytyjski premier - zdaniem autora - wyraźnie dał do zrozumienia, że uważa już Polskę za kraj dla Europy stracony i najwygodniej byłoby, aby w Warszawie wybuchła jakaś bolszewicka rewolta, a wówczas byłoby to wygodnym „usprawiedliwieniem” przed światem własnej bierności, bo to jakoby sami robotnicy polscy przejęli władzę

\footnotetext{
9 Należy również przypomnieć mało znany fakt, że już od maja 1920 roku organizowano w Niemczech bolszewicką armię z około 300 tysięcy rosyjskich jeńców z czasu I wojny światowej. Rosyjskie oddziały formowane na południu Niemiec transportowano przez Czechosłowację (a formowane w Prusach Wschodnich - przez Litwę) do Rosji, gdzie znacznie powiększyły siły Armii Czerwonej. W czasie wojny polsko-rosyjskiej niemieckie statki z Hamburga i Lubeki przewiozły do portów rosyjskich ponad 400 tysięcy karabinów (w tym ciężkie karabiny maszynowe), 200 milionów sztuk amunicji, kilkadziesiąt rozłożonych samolotów i podstawowe wyposażenie dla piechoty i kawalerii. Część broni i amunicji sprzedawana była za pośrednictwem Litwy oraz żydowskich kupców. Według relacji polskiego wywiadu w sierpniu 1920 roku w szeregach Armii Czerwonej walczyło około 20 tysięcy niemieckich żołnierzy, w tym dwa tysiące oficerów (telegrafistów, łącznościowców, saperów i artylerzystów, często w niemieckich mundurach i pikielhaubach, charakterystycznych niemieckich hełmach ze szpicem) oraz około 80 tysięcy „spartakusowców” (niemieckich komunistów). Sam Michał Tuchaczewski (dowódca rosyjskiego Frontu Zachodniego, który zaatakował Polskę) wspominał: „W Prusach Wschodnich, kiedy otarliśmy się o nie, popłynęły do nas setki i tysiące ochotników, spartakusowców i robotników bezpartyjnych pod sztandary Czerwonej Armii, tworząc w niej niemiecką brygadę strzelców", M. Tuchaczewski, Pochód za Wistę [w:] J. Pitsudski, Rok 1920. Z powodu pracy M. Tuchaczewskiego „Pochód za Wistę”, Łódź 1989, s. 181; Sasiedzi wobec wojny 1920 roku. Wybór dokumentów, opr. J. Cisek, Londyn 1990, s. 263-266; J. Goclon, W obronie Europy. Wojna z bolszewicka Rosja w 1920 roku, Komorów 2015, wyd. IV zmienione i poszerzone, s. 342-345. Zob też: Spisek niemiecko-bolszewicki. Dokumenty dotyczące związu bolszewików z niemieckim naczelnym dowództwem, wielkim przemysłem i finansami oraz reprodukcja fotograficzna dokumentów, Warszawa 1919; A. Skrzypek, Niespetniony sojusz? Stosunki sowiecko-niemieckie 1917-1941, Warszawa 1992.

10 Cyt. za: A. Nowak, Pierwsza zdrada zachodu ..., s. 185.

11 Ibidem, s. 186.
} 
w swoim kraju, a Armia Czerwona nie byłaby już najeźdźcą. Dla brytyjskiego premiera uderzenie bolszewickiej Rosji na Rzeczpospolitą miało nie mieć „nic wspólnego z komunizmem" ${ }^{2}$. Prezydent Francji pozostał jednak przy stanowisku, że należy - walczącą bohatersko - Polskę wspomagać aż do końca.

Najciekawszą partią monografii jest, zdaniem samego Autora książki, część trzecia, gdzie usiłował określić, opierając się na niewykorzystanych dotychczas dokumentach, przyczyny przyjęcia postawy appeasementu przez państwa ententy, a szczególnie przez brytyjskiego premiera, który obok premiera Francji odegrał największą rolę w ukształtowaniu powojennej Europy i żałosnej próbie „uspakajania” bolszewickiej Rosji, kosztem mniejszych państw środkowo-wschodniej części europejskiego kontynentu. Jest to rzeczywiście bogata analiza psychologiczna motywów najbardziej wpływowych polityków tamtej epoki, w kierunku ugody z nowymi władcami Moskwy.

W rozdziale tym autor przytacza życiorysy polityków - ze szczególnym uwzględnieniem epok, w których wyrastali, i wpływu tradycji rodzinnych domów - decydujących o polityce europejskiej w latach 1919-1920, takich jak: Arthur Balfour, Lewis Namier, Philip Keer, Maurice Hankey, George Rumbold, Dawid Lloyd George, Winston Churchill i George Curzon.

Pomimo przytaczania bardzo ważnych cytatów źródłowych i wysnuwania celnych wniosków, pojawia się jednak wrażenie, że przyjęcie takiej konstrukcji książki spowodowało pewne jej rozchwianie. Pierwsze dwa rozdziały miały zwartą i chronologiczną narrację, podczas gdy to swoiste „cofanie” się, i to kilkakrotne, do dzieciństwa i młodości wymienionych polityków (kształtowanych przy tym przez różne epoki) jednak tę wcześniejszą spójność wyraźnie rozsadza. Lepszym rozwiązaniem wydaje się umieszczenie takich wcześniejszych informacji biograficznych po prostu w przypisach, i to najlepiej u dołu strony. Przypisy na końcu rozdziałów rzadko są czytane, nawet te zbiorcze na samym końcu książek, co praktykuje się zresztą coraz rzadziej.

Ciekawym „polskim wątkiem” jest ukazanie roli Lewisa Namiera (właśc. Bersteina, urodzonego w Galicji Wschodniej, w spolszczonej żydowskiej rodzinie), sekretarza brytyjskiego premiera, na którego opiniach miał się - zdaniem autora - opierać szef rządu Lloyd George w swojej antypolskiej postawie, nie tylko w czasie konferencji pokojowej w Wersalu, ale również w 1920 roku (i nawet do końca swojego życia, usprawiedliwiając wkroczenie Armii Czerwonej na Kresy Wschodnie Rzeczypospolitej w 1939 roku) ${ }^{13}$.

Autor wyjątkowo trafnie ujął psychologiczny rys - tak bardzo niechętnego Polsce - brytyjskiego premiera, który zakładał wprawdzie, że „bolszewicy to barbarzyńcy, ale których przez handel, jak wszystkich innych barbarzyńców, można ucywilizować. Nie do poziomu brytyjskich obywateli zapewne, ale na pewno do poziomu normalnych uczestników europejskiej wymiany gospodarczej. Brytyjski liberał (radca prawny z zawodu - J.G.) nie mógł zrozumieć, że sami bolszewicy tak tego nie widzą". Czując się

12 Ibidem, s. 196.

13 Według Autora - Lewis Namier informował brytyjskiego premiera, że w Galicji Wschodniej mieszkało ,3,2 miliona grekokatolików, 1,15 miliona rzymskich katolików i 625 tysięcy żydów. Podkreśla jednak zaraz, że nie tylko nie wolno zaliczać żydów do ludności, która zgodziłaby się z polskim panowaniem w Galicji, ale także to, iż próby uznawania niektórych grekokatolików za propolskich są chybione, jak również, że nie każdy rzymski katolik może być uznany za Polaka. Dzięki takiej interpretacji danych statystycznych może stwierdzić następnie, że w żadnym zakątku Galicji Wschodniej nie występuje polska większość”. Ibidem, s. 251. 
„dyrygentem Europy, potrzebował coraz mniej rad, które mogłyby zmienić sposób jego myślenia. On wiedział najlepiej. Skoro coś trafiło raz do jego wyobraźni, wolał znajdować u swoich sekretarzy (jak Namier - J.G), doradców, ministrów wszystko to, co tej wizji odpowiadało, co ją potwierdzało. [...] «Grzechem» jego wizji polityki międzynarodowej była nie tylko ignorancja, lecz przede wszystkim arogancja niedouczonego brytyjskiego liberała, który w przekonaniu o słuszności swojej idei, a także o naturalnej wyższości swojego punktu widzenia nad optyką barbarzyńców spoza Wysp (Brytyjskich - J.G.), układa mapę świata, nie oglądając się na jego realne kształty. Był gotów te kształty zmienić. Ugoda z Rosją sowiecką - jak celnie podsumowuje Autor - mogła wzmocnić przekonanie o śmiałości własnej wizji. [...] Pokój przez handel. Handel - cudzymi ziemiami i interesami - przez pokój. Z Leninem" ${ }^{14}$. Przytoczyłem ten cytat, ponieważ rzadko w polskiej literaturze historycznej można spotkać tak trafne ujęcie postaw polityków decydujących o biegu dziejów.

Cześć czwarta monografii poświęcona jest sprawom polskim i tajnym rokowaniom polsko-rosyjskim w roku 1919, wyniku w których nie doszło jednak do zawarcia porozumienia, ale też Naczelny Wódz Józef Piłsudski nie zdecydował się - mimo znacznych nacisków mocarstw zachodnich - na poparcie „białych armii” carskich generałów walczących z Armią Czerwoną o przywrócenie ustroju państwa rosyjskiego sprzed bolszewickiego przewrotu w 1917 roku. Główną przyczyną był brak rosyjskich obietnic uznania ziem zabużańskich na rzecz niepodległego państwa polskiego, a nawet niepodległości państw Kaukazu i państw bałtyckich - na to Piłsudski nie chciał się zgodzić. Nie można zapominać, że carski generał Anton Denikin (jego matką była Polka), uznawany przez państwa ententy za przyszłego władcę Kremla - żądał od wojsk polskich wkraczających na Kresy Wschodnie, aby Polacy przejmowali te tereny wyłącznie w imieniu „białej” Rosji i na gmachach urzędów zawieszali godło z dwugłowym carskim orłem...

A co niosła Armia Czerwona Polsce i Europie? Już po podpisaniu rozejmu (12 października 1920 roku) i ustaniu działań wojennych Lenin publicznie głosił, że zbolszewizowanie Polski otwierało drogę do Niemiec i oznaczało „kres całej polityki międzynarodowej, gdyż opiera się ona tylko na traktacie wersalskim, a traktat wersalski jest traktatem drapieżców i rozbójników"15.

Marsz Armii Czerwonej był śmiertelnym zagrożeniem nie tylko dla Polski, ale również dla całej Europy. „Jeszcze kilka dni zwycięskiej ofensywy - mawiał Lenin - a nie tylko Warszawa byłaby zdobyta [...] lecz rozbity byłby pokój wersalski”"16. Oczywiście rosyjscy komuniści liczyli nie tyle na podbój europejskiego kontynentu wyłącznie siłami Armii Czerwonej, bo to nie było możliwe, ile na wzniecenie ogólnoeuropejskiej

14 Ibidem, s. 354.

15 Ibidem, s. 487.

16 W. Lenin, O Polsce i polskim ruchu robotniczym, Warszawa 1954, s. 500. Niezwykle „,barwnie” rosyjską klęskę ,uzasadnił” J. Jurkiewicz (Nuncjatura Achillesa Ratti w Polsce, Warszawa 1955, s. 60), pisząc: „Ani pomoc Ententy, ani wysiłki Watykanu nie uratowałyby reakcji polskiej, gdyby nie zdrada Trockiego i Tuchaczewskiego, wskutek której ofensywa Czerwonej Armii została powstrzymana. Lecz interwenci nie mieli już możliwości dalszego kontynuowania wojny i dlatego doszło do zawarcia traktatu pokojowego w Rydze". Zob. też: Z. Brzeziński, Wielkie bankructwo. Narodziny i śmierć komunizmu w XX wieku, Paryż 1990; Z. Olszański, Ksztattowanie się wschodniej granicy odrodzonej Polski 1918-1921, Bemowo 1990; H. Dominiczak, Granica wschodnia Rzeczypospolitej Polskiej w latach 1919-1939, Warszawa 1992; J. Smaga, Narodziny i upadek imperium ZSRR 1917-1991, Kraków 1992. 
rewolty i przejmowanie władzy w poszczególnych krajach przez miejscowych komunistów wszędzie tam, gdzie dotarłyby rosyjskie dywizje. Było to bardzo realne zagrożenie w Europie wyniszczonej wojną i tym samym podatnej na radykalne hasła. Rosyjscy komuniści nieśli jedynie powszechną grabież, demoralizację całych narodów i - nieznane wówczas na taką skalę - ludobójstwo! To Polacy stanęli na drodze pochodu Armii Czerwonej i nie dopuścili do połączenia rosyjskiej rewolucji z niemiecką - ratując tym samym kontynent europejski od zalewu bolszewickiego barbarzyństwa ${ }^{17}$.

Monografia jest pozycją wyjątkową i bardzo starannie wydaną, zawierającą również mało znane fotografie z epoki, w której ważyły się losy Rzeczypospolitej. W wypadku klęski w wojnie z bolszewicką Rosją Polska zostałaby wtrącona w otchłań komunistycznego piekła, w jego okrutnej, rosyjskiej odmianie, co spotkało inne narody, i tracąc niepodległość w 1920 roku, najprawdopodobniej już by jej nie odzyskała w 1945. Nawet w tak bardzo okrojonej formie, jaką była PRL.

Na szczególną uwagę zasługuje nie tylko styl pisarstwa autora, wciągający czytelnika, ale przede wszystkim bardzo odważne, stanowcze stawianie tez, opartych często na cytatach ze źródeł, co naturalną koleją rzeczy jest dla czytelnika wyjątkowo przekonywujące.

Wszystko to czyni tę wartościową naukowo monografię dla zawodowych historyków godną polecenia także szerszemu gronu czytelników.

17 J.A. Goclon, W obronie Europy. Wojna z bolszewicka Rosja w 1920 roku..., s. 426. 